\title{
PROBLEM SOLVING OF NON-EQUIVALENCE PROBLEMS IN ENGLISH INTO INDONESIAN TEXT
}

\author{
Widhiya Ninsiana \\ Institut Agama Islam Negeri (IAIN), Metro \\ Email: tantowidi@yahoo.co.id
}

\begin{abstract}
In the process of transferring one message of Source Language (SL) to Target Language (TL) in a translation must be careful by a translator, because one word may have more than one meaning. By knowing the possible meanings of a word, the meanings appropriately should be translated by a translator, and the readers will get the meaning and information of the target text. The equal meaning of source language to the target language is equivalnce, but non-equivalence occurs when the meaning in source language is not translated into the target language. There are many strategies to solve the problems of non-equivalence in Indonesian into English. A translator has a strategy to solve it. These strategies, that is, cultural, loan word, pharaphase, omission, semantically, hyponyms, etc.
\end{abstract}

Keywords : Translation, Equivalence and Non-equivalence

\section{INTRODUCTION}

Equivalence can be said to be the central issue in translation. The notion of equivalence is undoubtedly one of the most problematic and controversial areas in the field of translation theory. A translator must look for the equivalence between Source Language (SL) and Target Language (TL), so that there is no missing information when he transfers the message from SL to TL.

Translating is not easy because every language has its own rules in phonetic, structure, and words. In translating text, sometimes the translator finds problems of equivalence and non-equivalence in the text. The translator will use certain strategies to solve those problems. By using the strategies, the text can be more understood by the readers from the target language.

\section{Concept of Translation}

Some experts have defined their own definition about translation. Douglas Robinson states that definition of translation depends on people's point of view. Different people will give different definition. If they are not translator, they argue that translation is primarily a text but if they are, translation is an activity (Douglas Robinson, 2007: 70). While according to Nababan (2008:18), he describes translation as process of transfering massage from Source Text to Target Text. Moreover he argues that in translation needs to understand the meaning and also the figurative language. It is important because the massage of the text usually found after 
the translator take awareness in figurative language that author delivered.

Bell (1991: 5) explains that translation is the utterance to another language of what has been expressed in other source language, maintaining semantics and stylistics equivalences. Translation is a general term referring to the transfer of thoughts and ideas from one language to another, whether the language is in written or oral form, whether the languages have established orthographies or not; or whether one or both languages is based on signs, as with signs of the deaf.

Another expert, Wilss states that translation is a transfer process which aims at the transformation of a written source language text (SLT) into an optimally equivalent target language text (TLT), and which requires the syntactic, the semantic, and the pragmatic understanding and analytical processing of the source text.

In line with the definition, Catford gives a definition of translation is the substitution of textual material in one language (source language) by equivalent textual material in another language. In other word, translation is transform a language into another language equivalent (1965:20).

According to Samuelson, he emphasizes that translation is not a brief process, but it is a creative process (2010:XV). It needs some skills to be used together. The translator should unterstand what the writer means and then it is transfered in the target language. In the process of transfering massage, the interpreting and editing skill must be known well by the translator.
In the same line, Machali explains that translation is a product and a process (2000:9). It is called a product because a readable written text, and called a process because a translator always passes many steps in translating process. Even though the readers never know the process itself but translator still aware in choosing suitable method, find the suitable term and so on.

Based on the explanation above, it can be inferred that translation is a creative process of transfering massage from SL into TL that produces a readable and understandable written text.

\section{Kinds of Translation Method}

Newmark (1998:45) lists the following translation methods, which essentially fall along a cline of focus, one extreme being total focus on the source text/language and the order extreme being total focus on the target text/language:

a. Word of Word Translation

The SL word order is preserved and the words translated by their most commons meaning cultural words are translated literally. The main use of this is either to understand the mechanics of the source language or construe a difficult text as pre-translation process. Example, English into Indonesian :

SL: I'm invited?

TL: Aku diundang?

Based on the example above, the translator translated text every word without changing the form of text. It means that one word has one meaning. It can be proven word $I^{\prime \prime} m$ is translated into aku and invited? is translated into diundang?. Thus, 
the datum I'm invited? transferred into target language Aku diundang? belongs to wordfor-word translation.

b. Literal translation

The SL grammatical constructions are converted to their nearest TL equivalents but the lexical items are again translated out of context. As pretranslation process, it indicates problems to be solve.

Example : SL : Don" $t$ bring my book.

TL : Jangan bawa

bukuku.

Referring example above there is difference between the grammatical construction of the source language and the target language. Word $m y$ is translated $k u$, it shows that the translator started translating word by word, after that the grammatical construction between source language and the target language is repaired so that don "t bring my book which is translated into jangan bawa bukuku. The difference is word $m y$ in the middle of sentence is changed in the end of sentence. It can be concluded that it belongs to literal translation.

c. Faithful translation

It attempts to reproduce the precise contextual meaning of the original within the constraints of the TL grammatical structure. It transfers cultural words and preserves the degree of grammatical and lexical deviation from SL norms. It attempts to be completely faithful to the intentions and the text-realization of the SL writer. Below eaxmple :

SL : JokoWidodo was a

Javanese

TL : Joko Widodo adalah orang Jawa

d. Semantic translation

It may translate less important cultural words by culturally neutral third or functional terms but not cultural equivalent and it may make other small concessions to the readership. Example:

TL : He is a book-worm

SL : Dia kutu buku.

e. Communicative Translation

It attempts to render the exact contextual meaning of the original in such a way that both language and content are readily acceptable and comprehensible to the readership.

Example : SL : Beware of dog

TL: Awas Anjing

Translation methods relate to the whole texts, on the other hand translation procedures are used for sentences and the smaller units of language. Transference is the process of transferring the source language word to a target language text a translation procedure.

f. Idiomatic Translation

It reproduces the message of the original but tends to distort nuances of meaning preferring colloquialisms and idioms.

Example: SL: Most of the white paint has been chipped away.

TL: Sebagian besar cat putihnya sudah mengelupas 
g. Free Translation

It reproduces the matter without the manner, or the content without the form of the original. Usually it is paraphrase much longer than the original.

Example: SL: I had never been invited to any of the parties at my school before.

TL: $\quad A k u$ belum pernah diundang ke pesta apapun.

h. Adaptation

This is the freest form of translation mainly used for plays and poetry: themes/character/plots preserved, SL culture converted to TL culture and text is rewritten. Example :

SL : The rising sun is found not to be the rising sun.

It is the world which goes round.

TL : Matahari terbit ternyata bukan matahari terbit.

Dunialah yang sebenarnya mengorbit.

\section{Translation Equivalence}

Equivalence is most important in translation. Equivalence can be said to be the central issue in translation. Findings equivalence in a text is not easy. When a translator translate a text, he must be careful it. He needs some strategies to find equivalence in source language into target language.

Finding one to one equivalent in the target language is not easy (Newmark, 1995:294), as most languages are likely to have equivalents for the more general verbs of speech such as say and speak, but many may not have equivalents for the more specific ones (Suryawinata and Hariyanto, 2003).
The notion of equivalence is undoubtedly one of the most problematic and controversial areas in the field of translation theory. A translator must look for the equivalence between $\mathrm{ST}$ and TT, so that there is no missing information when he transfers the message from ST to TT (Venuti 2000:133).

Baker (1998:77) defines equivalence as the relationship between a source text (ST) and a target text (TT) that has allowed the TT to be considered as a translation of the ST in the first place

One of problems in translation process is finding the nature of equivalence. Further, Bell, T. Roger. (1991: 6) states that texts in different languages could be equivalent in different degrees (fully or partially equivalent) in respect of context, of semantics, of grammar, of lexis, etc) and at different ranks (word-for-word, phrase-for-phrase, sentence-forsentence). Vinay and Darbelnet (in Munday, 2001: 58) stated that "equivalence refers to cases where languages describe the same situation by different stylistic or structural means". Equivalence is a state of being equal.

Translation involved two equivalent messages in two different codes. From a grammatical point of view languages may differ from one another to a greater or lesser degree, but this does not mean that a translation cannot be possible. For the message to be equivalent ${ }^{\text {ee }}$ in source language and larget language, the code sometimes will be different since it belongs to two different languages which partition reality differently.

From those definitions, Equivalence was meant to indicate that Source Language (henceforth SL) and 
Target Language (henceforth TL) share some kind of sameness.

\section{Types of Equivalence}

Types of equivalence according to Nida which are stated in (Munday, 2001, p. 41) which are: (1) formal equivalence and (2) Dynamic equivalence.

Nida defined these as follows: Formal equivalence focuses attention on the message itself, in both form and content. Viewed from this formal orientation, one is concerned that the message in the receptor language should match as closely as possible the different elements in the source language. This means, for example, that the message in the target culture is constantly compared with the message in the source culture to determine standards of accuracy and correctness (Venuti 2000:129)

a. A formal equivalence attempts to reproduce several formal elements, including: a) grammatical units; b) consistency in word usage, and 3) meaning in terms of source context. Nida also calls this kinds of equivalence as 'gloss translation', which aims to allow the reader to understand as much as the ST context as possible.

b. Dynamic equivalence is based on what Nida calls 'the principle of equivalent effect', where 'the relation between receptor and message should be substantially the same as that which existed between the original receptors and the message'. One way of defining a dynamic equivalence translation is to describe it as "the closest natural equivalent to the SL message." This kind of definition contains three essential items: a) equivalent, which points toward the SL message, b) natural, which points towards the TL, and 3) closest, which binds the two orientations together on the basis of the highest degree of approximation.

A translation of dynamic equivalence aims at complete naturalness of expression, and tries to relate the receptor to modes of behavior relevant within the context of his own culture; it does not insist that he understand the cultural patterns of SL context in order to comprehend the message.

Equally important in the translation work is finding equivalence. The principal purpose of any translation should be to achieve 'equivalent effect' i.e. to produce the same effect (or one as close as possible) on the readership of the translation as was acquired on the readership of the original (Newmark, 1995:48). Finding one to-one equivalent in the target language is not easy as most languages are likely to have equivalents for the more general verbs of speech such as say and speak, but many may not have equivalents for the more specific ones (Suryawinata and Hariyanto, 2003). Nonequivalence occurs when the message in the source language is not tranferred equally to the target language.

Catford's model of equivalence as cited in Munday (2001: 60) devided:

1. Formal correspondence is any TL category (unit, class, element of structure, etc) which can be said to occupy as nearly as possible the "same" place in the "economy of the TL as the given SL category occupies in the SL. For example: translating an adjective by an adjective. 
2. Textual Equivalence is any TL text or portion of text which is observed on a particular occasion to be the equivalent of a given SL text or portion of text. For example: translating adjective by an adverbial phrase.

Popovic (as cited in Susan Basnett, 1998:32) distinguishes four types, namely :

1. Linguistic equivalence, where there is homogeneity on the linguistic level of both SL and TL texts, i.e. word for word translation.

2. Paradigmatic equivalence, where there is equivalence of 'the elements of a paradigmatic expressive axis', i.e. elements of grammar, which Popovic sees as being a higher category than lexical equivalence.

3. Stylistic (translational) equivalence, where there is 'functional equivalence of elements in both original and translation aiming at an expressive identity with an invariant of identical meaning'.

4. Textual (syntagmatic) equivalence, where there is equivalence of the syntagmatic structuring of a text, i.e. equivalence of form and shape.

$$
\text { Baker (1992) divides }
$$

equivalence into several types:

a. Equivalence at word level and above word level

Baker acknowledges that, in a bottom up approach to translation, equivalence at word level is the first element to be taken into consideration by translator. In fact, when the translator starts analyzing the ST, the translator looks at the words as single units in order to find a direct 'equivalence' term in the Target Language.

b. Grammatical Equivalence

Baker states the grammatical rules may vary across languages and this may pose some problems in term of finding a direct correspondance in TL. In fact, she claims that the different grammatical structures in the SL and TL may cause remarkable changes in the way the information or message is carried across. These changes may include the translator either to add or to omit information in the Target Text bacause of the lack of particular grammatical devices in TL itself. Amongs these grammatical devices which migh cause problems in translation focuses on number, tense, aspect, voice, person and gender.

c. Textual Equivalence

Baker writes that "this type of equivalence refers to the equivalence between a SL text and a TL text in the term of information and cohesion. Texture is a very important feature in translation since it provides useful guidelines for the comprehension and analysis of the source text, which can help the translator in his or her attempt to produce a cohesive and coherent text for the target language audience in a specific context".

d. Pragmatic Equivalence

It deals with coherence and implicature. Pragmatic equivalence looks at how texts are used in communicative situations that involves variables, such as writers, readers and cultural context. In other words, pragmatic equivalence focuses on implied meaning. 


\section{Problem of Non-Equivalence}

Non-equivalence happens at word level. It means that target language (TL) has no direct equivalence for a word which occurs in the source language. There are many possible problems of non-equivalence between two languages. Non-equivalence occurs when the message in the source language is not tranferred equally to the target language.

According to Mona Baker (1992:20), non-equivalence at word level means that the target language has no direct equivalent for a word which occurs in the source text. The common problems of non-equivalence at word level include: (1) culture specific concept, (2) the sourcelanguage concept is not lexicalized in the target language, (3) the source language word is semantically complex, (4) the source and target languages make different distinctions in meaning, (5) the target language lacks a superordinate, (6) the target language lacks specific term (hyponyms), (7) differences in physical or interpersonal perspective, (8) differences in expressive meaning, (9) differences in form. (10) differences in frequency and purpose of using specific form, and (11) the use of loan words in the source text.

\section{a. Culture-specific concepts}

Based on this problem, the source-language word may express a concept that is totally unknown in the target language culture. The concept may be abstract or concrete; it may relate to a religious belief, a social custom, or even a type of food. For example, the word privacy is a very 'English' concept, which is rarely understood by people from other cultures. Example:

SL: Panggil saya 'mas'.
TL: Call me 'honey'.

The word 'mas' in the dialog above is translated into 'honey' in English. However, in different context, of course, the word 'mas' cannot be translated as 'honey', for example when it is used to address one's older brother.

It is possible to come across a word which communicates a concept in the source target that is unknown in the target culture. This concept could be abstract or concrete, it could refer to a social custom, a religious belief, or even a type of food.

\section{b. The Source-Language Concept is} not Lexicalized in the Target

Language

This problem occurs when the source language expresses a word which easily understood by people from other culture but it is not lexicalized. For example, the word savoury has no equivalent in many languages, although it expresses a concept which is easy to understand. It means that a concept that is known by people in some areas does not always have the lexis in every area.

c. The Source Language Word is Semantically Complex

The source - language word be semantically complex. This was fairly common problem in translation. Words did not have to be morphologically complex to be semantically complex (Bolinger and Sears, 1968:55). In other words, a single word which consisted of a single morpheme could sometimes express a more complex set of meaning than a whole sentence. For example the word "tengkurap" in Indonesian Language which meant sleep with body faced ground. 
d. Source and Target Language Make Differences in Meaning

Baker (1992:11) stated what one language regards as an important distinction in meaning another language might not perceived as relevant. For example the word "kepanasan" in Indonesian language which meant going out in strong bright of sun without the knowledge that today the sun will extremely hot and going out with the knowledge that today the sun will extremely hot (panas-panasan). English did not make any distinction of those words, so it would be difficult to find the equivalence.

A translator sometimes makes different meaning of the source and target text. One expression in the source text might be differently expressed in the target text. As an example, in the sentence 'She was going out in the snow', it can be understood differently in Indonesian: 'Dia pergi keluar tanpa tahu kalau salju sedang turun' or 'Dia sengaja pergi keluar walaupun salju sedang turun'. In this case, the translator must be quite aware of the context in the source text.

e. The Source and Target Languages Make Different Distinctions in Meaning

What one language regards as an important distinction in meaning another language may not perceive as relevant. The target language may make more or fewer different distinction in meaning than the source language. For example : English has some specific term for 'house' as 'bungalow', 'cottage', 'villa', 'hall', 'lodge', and 'mansion'. Javanese, on the other hand, also has some specific terms related to plants as 'manggar', 'bluluk', 'cengkir', 'degan', 'klopo', and 'cumplung' which is not found in Indonesian and English.

f. The Target Language Lacks a Superordinate

The target language may have specific words (hyponym) but not the general one. Russian has no ready equivalent for facilities, meaning 'any equipment, building, services, etc. that are provided for a particular activity or purpose'. It does however, have several specific words and expressions which can be thought of as types of facilities. Example;

SL: She had jewelry and several socks filled with guilders that she had saved and

hidden in her mattress

TL: Dia memiliki perhiasan dan beberapa kaus kaki berisi uang logam perak

The word guilders means the unit of money in the Netherlands. However, the translator chooses to translate it as uang logam perak since she finds a more general word that covers the basic meaning. Therefore, it is not necessary to translate the whole idea into Indonesian because the basic message, namely she had guilders, will be spoiled since the readers will pay attention more on the explanation about guilders causing the effect which will not be equivalent.

g. The Target Language Lacks
Specific Term (Hyponyms)
The problem of non-equivalence is that the target language lacks a specific term (hyponym). Usually, languages tend to have general words (super ordinate), but lack the specific ones (hyponyms), since each language makes only those distinctions in meaning which seem relevant to its particular environment. The example 
for this problem is English has many hyponyms under article for which it is difficult to find precise equivalents in other languages. Feature, survey, report, critique, commentary, review, and many more. Another example from Indonesian word is membawa. The word membawa has some specific term, which does not have direct equivalent in English; they are menjinjing, menyunggi, and memanggul.

h. Differences in Physical or Interpersonal Perspective

Baker (1992) notes that the TL may make more or fewer distinctions in meaning than the SL. A word in English might conveys additional meanings relative to Vietnamese one, hence, it makes translators confused which words to be used properly provided that the context itself offers them enough detailed information. The physical perspective concerns the location of things or people in the context with others. For example, in English, "come" means getting closer to the place where the speaker is or is to be while "go" means getting away from the speaker. The same explanation for other pairs such as "take- bring".Vietnamese does not make such a distinction

i. Differences in Expressive Meaning Differences in Form

There is often no equivalence in the target language for a particular form in the source text. Certain suffixes and prefixes which convey prepositional and other types of meaning in English often have no direct equivalents in other languages. For example, English has many couplets such as employer/employee, trainer/trainee, and payer/payee. It also makes frequent use of suffixes such as ish (e.g. boyish, hellish, greenish) and -able (e.g. conceivable, retrievable, drinkable). Arabic, for instance, has no ready mechanism for producing such forms and so they are often replaced by an appropriate paraphrase, depending on the meaning they convey (e.g. retrievable as 'can be retrieved' and drinkable as 'suitable for drinking'). It is important for the translator to understand the use of affixes because it is often used to coin new words.

j. Differences in Frequency and Purpose of Using Specific Form

Even when a particular form had a ready equivalent in the target language, there might be a difference in the frequency with which it was used or the purpose it is used. For example English used the continuous -ing form for binding clauses mush more frequently than other languages which had equivalents for it, for example German and Scandinavian languages, yet the result would be stilt and unnatural style.

$\mathrm{k}$. The Use of Loan Words in the Source Text.

Once a word is loaned into a particular language, we cannot control its development or its additional meaning. For example, dilettante is a loan word in English, Russian, and Japanese; but Arabic has no equivalent loan word. This means that only the prepositional meaning of dilettante can be rendered into Arabic; its stylistic effect would almost certainly have to be sacrified. Loan words also pose another problem for the unwary translator namely the 
problem of false friends, or faux amis as they are often called (Baker: 1992). Translators should be more careful when they face the loan words in the process of translating a text.

\section{DISCUSSION}

Non-Equivalence Strategies at Word Level

Translation by more general word (super ordinate)

This is one of the commonest strategies with many types of nonequivalence, particular in the area of propositional meaning. It works equally well in most, if not all, languages, since the hierarchal structure of semantic fields is not language - specific. For example:

SL : ......you barbarian

TL : ......dasar bandit

The word barbarian is translated into bandit. The word barbarian means orang biadab. The word barbarian descriceb a crude uncouth ill-bred personlacking culture or refinement. The word barbarian have a number of different meanings. They are barbaric, savage, uncivilised, uncivilized, wild. However, to translate the word barbarian in the TL into the accurate meaning. The translator used a strategy that is using a by more general word. This strategy is applied for the sake of the readability in the target readers. The word barbarian is then translated the word bandit to sound more general for the Indonesian readers.

\section{Translation by a more neutral/less expressive word}

This strategy involves replacing a culture specific item or expression with a target-language item which does not have the same propositional meaning but is likely to have a similar impact on the target reader. There are three data identified with this strategy, example below.

SL: I will prove the old hag wrong

TL: Akan kubuktikan bahwa si nenek itu salah

\section{Translation by cultural substitution.}

This strategy is called "cultural equivalent" (Newmark, 1988:82-83). It involves "replacing a culturespecific item or expression Universitas Sumatera Utara with a target language item which does not have the same propositional meaning" (Baker, 1992: 30). The main advantage of using this strategy is that it gives the reader a concept with which s/he can identify something familiar and appealing.

Translation using a loan word or loan word plus explanation

In this strategy, the cultural terms are not translated or the translation still uses the source language's terms. It happens since the translator finds difficulty to translate the culture specific items and modern concepts. Following the loan word with explanation is very useful to make the readers fully understand the term. For example:

SL : ... to remove the string of empty cans their friends had tied to the rear bumper

TL: ... untuk melepaskan tali pengikat kaleng-kaleng kosong yang diikatkan teman-teman mereka di bumper belakang mobil

The word of bumper is translated as same as the source language. Bumper is the front-most or rear-most part, ostensibly designed to allow the car to sustain an impact 
without damage to the vehicle's safety systems. However, it is difficult to find the equivalence of translation in the target language. So, bumper is used in the target text, and, moreover, such word is familiar in automotive field for Indonesian readers.

\section{Translation by paraphrase using a related word}

This strategy tends to be used when the concept expressed by the source item is lexicalized in the target language but in a different form. The writer found eighteen data with this strategy, as illustrated in two data below.

SL: Rio asked her to marry him, rather than asking her family

TL: Rio melamarnya langsung dan bukan mendatangi keluarganya

The phrase rather than asking is translated as dan bukan mendatangi. They are really two different in meaning. In this case, the translator prefers to paraphrase it by using unrelated words than by its actual meaning, namely daripada meminta kepada keluarganya in order to achieve a high level of precision in specifying the basic meaning. Though no relations, the target language is more natural and general for Indonesian readers.

a. Translation by paraphrase using unrelated words

The paraphrase strategy can be used when the concept in the source item is not lexicalized in the target language. When the meaning of the source item is complex in the target language, the paraphrase strategy may be used instead of using related words; it may be based on modifying a super-ordinate or simply on making clear the meaning of the source item.
S1 : Ririn looked pleased as the Dora Emon finally engulfed the tip of her nose

TL: Ririn kelihatan senang. Hidungnya sudah hampir_tertutup es krim

The phrase finally translated as sudah hampir. They are really two different in meaning. In this case, the translator prefers to paraphrase it by using unrelated words than by its actual meaning, namely selesai tertutup es krim in order to achieve a high level of precision in specifying the basic meaning. Though no relations, the target language is more natural and general for Indonesian readers.

b. Translation by omission

This strategy may sound rather drastic, but in fact it does no harm to omit translation a word or expression in some context. If the meaning conveyed by a particular item or expression is not vital enough to the development of the text to justify distracting the reader with lengthy explanation, translator can and often do simply omit translating the word or the expression in question. Example :

SL: They should be about ready

TL : Seharusnya sudah hampir jadi

The translator here omits the word they. They here refers to the pastries since to the previous sentence, it is mentioned that Carolien is baking cheese rolls for her breakfast. Therefore, the translator does not necessary to attach they referring to kue-kue due to its co-text. Therefore, the omission here is acceptable and remains to give the same effect for readers. 


\section{Non-Equivalence Strategies at above Word Level}

The non - equivalence problems of translation are not only occurred on the word level. In fact, words are combined with other words and make a new meaning. This combining words generally known as idioms, phrase, and fixed expression. Baker (1992: 65) mentions that there are two main problems of idiomatic and fixed expressions pose in translation. They are: the ability to recognize and interpret an idiom correctly; and the difficulties involved in rendering the various aspect of meaning that an idiom or fixed expression conveys into the TL. To overcome the problems above, Baker mention several strategies which are working on these combining words such idiom, phrase and fixed expression. There are several strategies that Baker has stated, they are:

\section{a. Using an Idiom of similar meaning and form}

This strategy involve using an idiom in the TL which roughly the same meaning as that the SL idiom and in addition consist of equivalent lexical item. This kind of match can only occasionally be achieved.

SL: I hope my dream come true

TL: Saya berharap impianku menjadi kenyataan

b. Using an idiom of similar meaning but dissimilar form

It is often possible to find idiom or fixed expression in the TL which has a meaning similar to that of source idiom or expression, but which consist of different lexical item. Example:

SL: The bandit was caught after he came out from his hideout

TL: Bandit itu ditangkap setelah keluar dari tempat persembunyiannya
c.Translation of paraphrase

This strategy has the same concept with the paraphrase strategy at word level, but the difference lied on the way it translated. At the word level, paraphrase strategy translates a word in to unrelated words, but in this paraphrase at this level, the idiom was translated into related idiom. This strategy is the most common way of translating idiom (Baker 1992:75). It possible for the translator find inaccurate paraphrase. Example:

SL: To improve english, you should learn new vocabulary on a daily basis

TL: Memperbaiki bahasa Inggris, kosakata baru seharusnya dipelajari setiap hari

The sentence above is translated by using paraphrase strategy. Since, the phraseology of the original cannot be reconstructed in the same syntactic way in the target language. The source language (SL) is translated you should learn new vocabulary on a daily basis into Indonesia kosakata baru seharusnya dipelajari setiap hari. By comparing between source language (SL) and target language (TL), it is clearly seen that target language (TL) is reconstructed in different syntactic.

\section{d. Translation by omission}

An idiom may sometimes be omitted altogether in the Target Language (TL) because it has no close match in the TL, its meaning cannot be easily paraphrased, or for stylistic reason.

SL : She hopes her future husband is a man of the world

TL : Dia berharap suaminya kelak adalah orang yang selalu memenuhi janjinya 


\section{CONCLUSION}

Translation equivalence and nonequivalence is always long to achieve since it depends on the text, the translator, and the receptors. It is a fact that no matter how competent the translator is, the translation might lose a certain degree of meaning relative to the original text. Not only the linguistic but also the cultural gaps among languages create the possibility of non-equivalence in translation.

Obviously, the larger the gap is, the harder the translation process will be. Hence, it is a must for a translator to continuously improve the personal knowledge on various areas and cultures of different countries. Despite of the recommended strategies, the creativeness of a translator is particularly important as no book can cover all the cases happen in reality.

\section{REFERENCES}

Basnett, Susan and Mc Guire, Translation Studies, London: Longman, 1980

Baker, M. In Other Words: A Course Book on Translation. London: Routledge. 1992

Bolinger, D. and Sears, D. Aspects of Language. New York: Harcourt Brace Jovanovich. 1968

Budiarto,Langgeng, and Fardhani, Aan E.,A Practical Guide for Translation Skill, Malang: UIN Maliki Press, 2010.

Catford, J. C. A Linguistic theory of translation; An Essay In Applied. 1965

Douglas Robinson,Becoming A Translator: An Introduction to the Theory and Practice of
Translation, $2^{\text {nd }}$ edition. New York: Routledge, 2007

Hatim, Basil and Munday, Jeremy. Translation: An advance resource book. London and New York: Routledge. 2004

Machali, Rochayah, Pedoman Bagi Penerjemah,.Jakarta: Grasindo, 2000.

Nababan, $\quad$ M. Rudolf,Teori Menerjemah Bahasa Inggris, Yogyakarta: Pustaka Pelajar, 2008, Cet. 3.

Newmark, P, A Textbook of Tanslation, U.K. Prentice Hall International Ltd,1988

Nida, Eugene A and Charles R. Taber, The Theory and Practice of Translation. The United Bible Societies, 1982

Robinson, Douglas, Becoming A Translator: An Introduction to the Theory and Practice of Translation, $2^{\text {nd }}$ edition, New York: Routledge, 2007.

Samuelsson-Brown, Geoffrey, A Practical Guide for Translator, Great Britain: Short Run Press, $5^{\text {th }}$ edition. 2010

Suryawinata, Z dan Hariyono, Sugeng. 2003. Translation : Bahasan Teori dan Penuntun Praktis Menerjemahkan. Yogyakarta: Kanisius

$\mathrm{T}$ Roger, Bell, Translation and Translating: theory and practice, UK: Longman Group, 1991 